\title{
Geospatial Evaluation for Ecological Watershed Management II: Changes in Land Use-Land Cover Influence on Ecosystems Services
}

\author{
Isoken Aighewi ${ }^{1}$, Ali Ishaque ${ }^{2}$, Osarodion Nosakhare ${ }^{2}$ \\ ${ }^{1}$ Benedict College, Columbia, USA \\ ${ }^{2}$ University of Maryland Eastern Shore, Princess Anne, USA \\ Email: aighewii@benedict.edu, abishaque@umes.edu, oknosakhare@yahoo.com
}

Received 4 March 2014; revised 4 April 2014; accepted 14 April 2014

Copyright (C) 2014 by authors and Scientific Research Publishing Inc. This work is licensed under the Creative Commons Attribution International License (CC BY). http://creativecommons.org/licenses/by/4.0/

(c) (i) Open Access

\section{Abstract}

Ecosystem services are a key to human survival and global sustainability. Consequently, there is the need to avoid unscrupulous or unplanned land use practices that can compromise these services in addition to the ongoing changes in the global climate whose potentially negative impact are yet to be fully comprehended thus far. The primary objective of this study was to evaluate the Land use-land cover changes of some Eastern Shore sub-watersheds of Maryland from 1986-2006 and qualitatively assess the impact of the changes on some key ecosystem services. Landsat-TM data for Maryland Eastern Shore in the United States were analyzed in ENVI and ArcGIS environment and data interpreted qualitatively. The result showed that forest lands increased during the study period and thus enhanced carbon sequestration favorable for mitigating global warming in the area. Also, the extent of surface water cover increased slightly, possibly due to rising sea level and a thus a potential threat to biodiversity and barrier islands nearby. There was also a significant increase in urban lands due to population increase and thus increase in the extent of impervious layers that could lead to reduced surface runoff and increase the potential for surface water quality impairment; this could lead to a reduction in the capacity of surface water ecosystem to provide clean/recreational waters. The increase in the extent of surface water cover was at the expense of the wetlands that shrunk, thereby threatening the coastal ecosystem's ability to provide services such as storm and wave protection, nutrient cycling, and the protection of wildlife habitat. There was also a decrease in the extent of Agricultural lands which could lead to loss of food and fiber during the study period. There is therefore an urgent need to formulate or intensify existing policies to regulate land use from an ecological health standpoint in order to ensure sustainability of the various ecosystems within the watersheds of the Lower Eastern Shore of Maryland in the US, and similar coastal locations elsewhere. 


\section{Keywords}

\section{Land Use, Ecosystem Services, Ecological Health, GIS, Landsat, Wetlands, Surface Water}

\section{Introduction}

Ecological health is the essential link between human health and well-being and the health of the natural environment. Economic prosperity, quality of life and personal well-being rely on properly functioning natural systems; we rely on nature to provide a wide range of services, including the air we breathe, the water we drink and the food we eat [1]. In fact, many ecologists believe that ecosystem services might be the long-awaited key to sustainability [2], and the process of quantifying them is increasingly recognized as a valuable tool for efficient allocation of environmental resources [3]. The fate of our ecosystems-particularly the fragile coastal ones, depend to a large extent on anthropogenic activities such as land use [4]. Gergel et al., [5] reported that patterns of land use have changed dramatically during the last century especially in North America, and that such historic changes have left persistent legacies. Changes occurring on land affect water quality and thus the ecological health of the aquatic ecosystems; and have been correlated with the degradation of biological, chemical and physical properties of streams within the Chesapeake Bay watershed [6] and elsewhere. The Lower Eastern Shore watershed and Coastal Bays of Maryland-subsets of the Chesapeake Bay watershed have been experiencing rapid urbanization in the last decade with increase in real estate development and roads as obvious indicators. Jantz et al. [7] observed a 61\% increase in developed land within the Chesapeake Bay watershed between 1990 and 2000, with (64\%) of the new development occurring on agricultural lands and grasslands, while 33\% occurred on forested lands. As further growth in urban development is anticipated, so will the stressors within these sub-watersheds that can potentially compromise key ecosystem services. Menzie et al. [8] suggested the need for a holistic assessment of ecosystem services for specific regions on a long-term basis as a strategy for guiding policy decisions on sustainability of our environment. However, evaluating ecosystem health in relation to the ecological, economic and human health spheres requires integrating human values with biophysical processes [9]. Whereas the presence of satellite images and Geographic Information Systems (GIS) are increasingly being used successfully in recent times for capturing the spatio-temporal changes in biophysical processes on land (e.g., Merem et al., [10]), studies linking those land use/cover changes to ecosystems services or health nor the economic dimensions of the changes are rare. Consequently, this study was initiated to: 1) evaluate the historical Land use-land cover (LULC) changes in the Lower Eastern Shore watersheds of Maryland using remote sensing and geographic information systems (GIS) methods, and 2) qualitatively assess the possible impact of the changes detected on key ecosystem services or health within the sub-watersheds for the period investigated.

\section{Methods}

\subsection{Study Location}

This study was conducted in the Lower Eastern Shore watershed and coastal bays of Maryland which lies between longitudes $74^{\circ} 59^{\prime} 15.2^{\prime \prime} \mathrm{W}$ and $76^{\circ} 17^{\prime} 5.6^{\prime \prime} \mathrm{W}$ and latitudes $37^{\circ} 54^{\prime} 12.4^{\prime \prime} \mathrm{N}$ and $38^{\circ} 53^{\prime} 10.7^{\prime \prime} \mathrm{N}$. This site is located between the Atlantic Ocean and the Chesapeake Bay and drains approximately $5596.69 \mathrm{~km}^{2}$ in Wicomico, Somerset and Worcester counties; and some portions of Caroline and Dorchester counties.

Major land use in the area include cropland, forestry, pasture and urban; and water bodies include estuary, river/stream and wetlands. Nutria, a non-native rodent invasive species have been reported to be a menace to the wetlands near the Black water National Wildlife Refuge in the study area [11]. The area which is less than 100 feet above sea level includes a total of 23 sub-watersheds [12] (see Figure 1). The main economic activities in the Lower Eastern Shore are poultry production, grain farming-corn, soybeans and barley as well as fishery and tourism.

\subsection{Data Collection and Analysis}

Landsat 5 TM satellite data of Maryland (Path 14, rows 33 and 34) for 1986 (May 6), 1996 (May 1) and 2006 


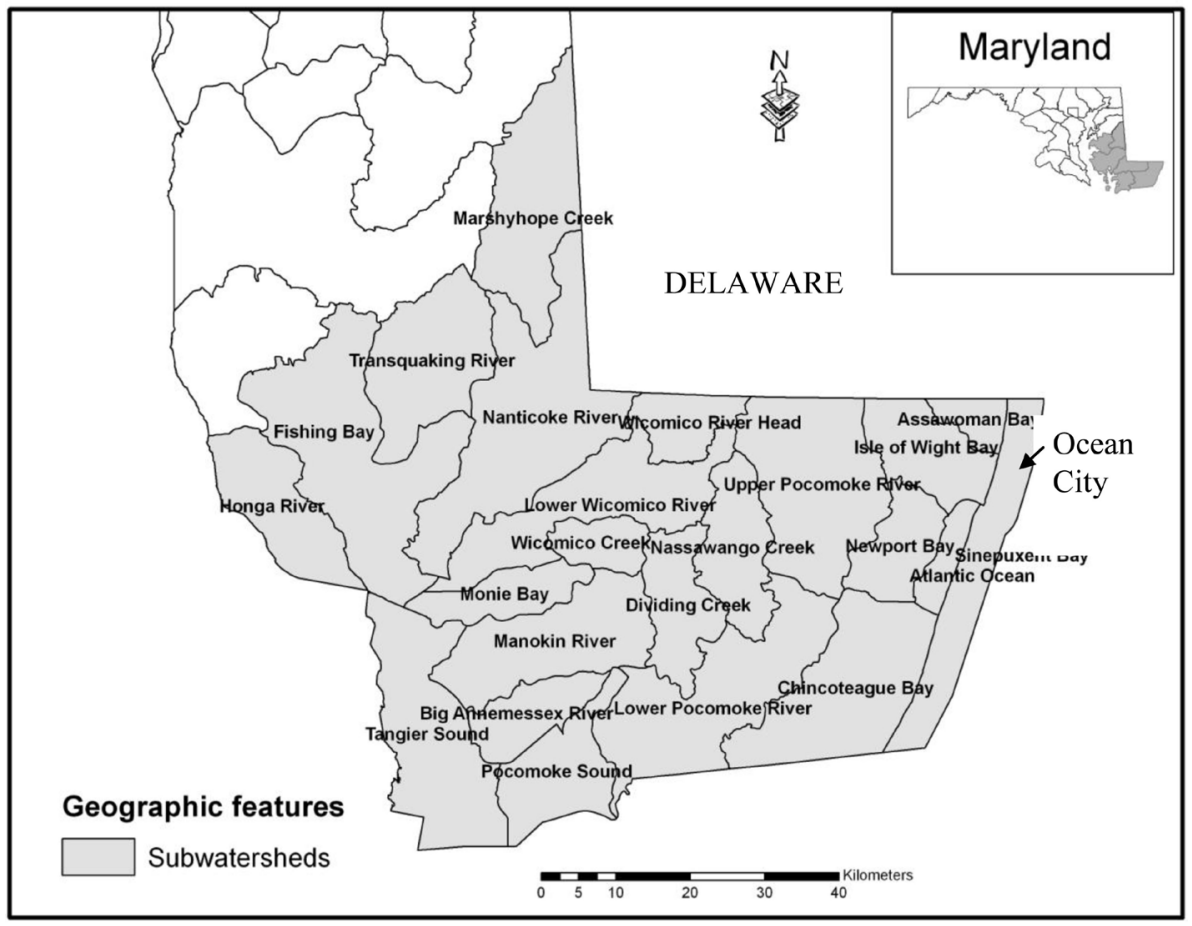

Figure 1. Study area showing the Lower Eastern Shore sub-watersheds of Maryland.

(April 27) were obtained in GeoTIFF format from United States Geological Survey (USGS) Center for Earth Resources Observation and Science (EROS). These images were of 10 days temporal variability (1986-2006) due to cloud cover and were systematically corrected; the data were of very high acquisition quality and had been geo-referenced and atmospherically corrected. The reflective bands $1-5$ and 7 were of pixel size of 30m, while the thermal band 6 was $60 \mathrm{~m}$. All maps were projected using NAD83 UTM Zone 18.

LULC classification for the study area was done in Environment for Visualizing Images (ENVI) acquired from ITT Visual Information Solutions. Bands 7, 4 and 2 were selected for supervised classification using Mahalanobis distance method after several trials. The reference group or regions of interest (R.O.I) selection was guided by aerial photos, Google Earth and ground-truthing and personal knowledge of the study area. LULC classification system of Anderson et al., [13] was used for classification. This classification system was originally developed to meet an up-to-date overview of land use and land cover throughout the United States on a basis that is uniform in categorization at the more generalized first and second levels and is receptive to data from satellite and aircraft remote sensors and has been extensively tested. The system classifies land use-land cover into nine major categories: Urban or built up land, Agricultural Land, Rangeland, Forest Land, Water, Wetland, Barren Land, Tundra, Perennial Snow or Ice at the level 1. However, rangeland, tundra and perennial snow land cover types are absent in the study location and were eliminated from the classification scheme. In this study, the classified images were further subjected to spatial analysis in ArcGIS [14].

The 1986 Landsat images for rows 33 and 34 were merged and each sub watershed was masked and extracted. Areas of various land use in each watershed were quantified by multiplying the number of pixels for each land use by the spatial resolution $(30 \mathrm{~m} \times 30 \mathrm{~m}$ ) of the Lands at images from which the LULC data was derived. Land use changes at 10-year intervals (1986-1996 and 1996-2006), and 20-year interval (1986-2006) were derived by overlaying the respective LULC maps for each interval. The Kruskal-Wallis one-way non-parametric analysis of variance test and the post-hoc pair was employed to evaluate how significant the land use/cover changed between each time intervals for the same area.

\section{Results}

\subsection{Historical Land Use-Land Cover Change in the Lower Eastern Shore of Maryland}

Some aspects of this study dealing with non-ecosystem services have been recently published [15]. The numeri- 
cal extent of change in land use/cover by class from 1986-2006 is also summarized in Table 1 and visually in Figure 2. During this period, forest lands and area covered by water increased by $8.5 \%$ and $10 \%$ respectively, while urban land increase by $121.8 \%$. However, there was a net loss of agricultural lands (19.6\%), wetlands (21.3\%) and barren lands (51.3\%) within the same period. The following are specific land use/cover changes that occurred for each class:

\subsection{Urban Land Use}

Table 2 summarizes the changes in land use classes during the first ten years and the entire 20-year period in vestigated for all sub-watersheds. All the sub-watersheds in the study area experienced increases in urban land use between 1986 and 2006 except the narrow coastal bays bordering the Atlantic Ocean and consisting of basically water (99.6\%) and beaches (0.2\%). The largest net gain in urban land occurred in the Lower Wicomico sub-watershed. Urban land increased by $18.26 \mathrm{~km}^{2}$ in the Lower Wicomico River sub watershed during the study period (11.37\%). Using the Kruskal-Wallis test and the post hoc paired comparisons, the Lower Eastern Shore sub-watersheds increased significantly $(\mathrm{P}<0.05, \mathrm{H}=9.87, \mathrm{n}=23)$ in urban land area between 1986 and 2006 after a total of $227.3 \mathrm{~km}^{2}$ of other land uses were converted to urban lands. However, changes between 1986-1996 and 1996-2006 intervals were not significant.

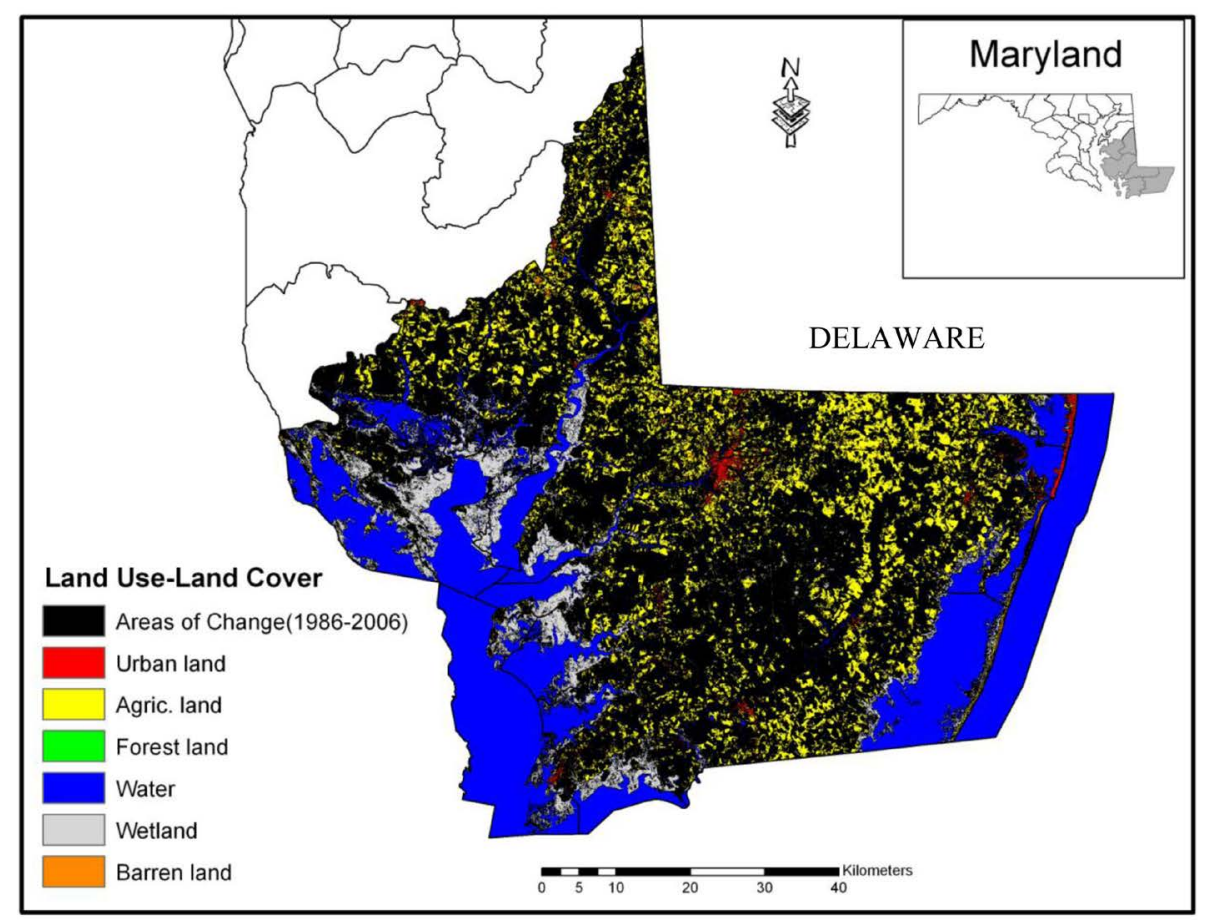

Figure 2. Land use-land cover change of Lower Eastern Shore of Maryland (1986-2006).

Table 1. Historic land use--land cover in Maryland Lower Eastern Shore (1986-2006).

\begin{tabular}{|c|c|c|c|c|c|c|c|c|}
\hline \multirow{2}{*}{ Land Use-Land Cover } & \multicolumn{2}{|c|}{1986} & \multicolumn{2}{|c|}{1996} & \multicolumn{2}{|c|}{2006} & \multicolumn{2}{|c|}{ Net Change } \\
\hline & $\left(\mathrm{Km}^{2}\right)$ & $\%$ & $\left(\mathrm{Km}^{2}\right)$ & $\%$ & $\left(\mathrm{Km}^{2}\right)$ & $\%$ & $\left(\mathrm{Km}^{2}\right)$ & $\%$ \\
\hline Urban & 115.4 & 2.1 & 1.1 .4 & 2.9 & 255.9 & 4.6 & 140.6 & 121.8 \\
\hline Agric & 1306.9 & 23.4 & 1121.5 & 20 & 1050.8 & 18.8 & -256.2 & -19.6 \\
\hline Forest & 2022.6 & 36.2 & 2136.1 & 38.2 & 2193.9 & 39.2 & 171.3 & 8.5 \\
\hline Water & 1365.5 & 24.4 & 1439.1 & 25.7 & 1501.4 & 26.8 & 135.9 & 10 \\
\hline Wetland & 7.4 .3 & 12.6 & 719.6 & 12.9 & 554.2 & 9.9 & -150 & -21.3 \\
\hline Barren & 80.2 & 1.4 & 17.2 & 0.3 & 38.7 & 0.7 & -41.6 & -51.3 \\
\hline Sum & 5594.8 & 100 & 5594.8 & 100 & 5594.8 & 100 & 0 & \\
\hline
\end{tabular}


Table 2. Net change in land use/cover of some Maryland Eastern Shore sub-watersheds (1986-2006).

\begin{tabular}{|c|c|c|c|c|c|c|c|c|}
\hline \multirow[t]{2}{*}{ SUB-WATERSHEDS } & \multicolumn{2}{|c|}{$\begin{array}{l}\text { Change in Wetland } \\
\qquad\left(\mathrm{Km}^{2}\right)\end{array}$} & \multicolumn{2}{|c|}{$\begin{array}{l}\text { Change in Agricultural } \\
\text { Lands }\left(\mathrm{Km}^{2}\right)\end{array}$} & \multicolumn{2}{|c|}{$\begin{array}{l}\text { Change in Forest lands } \\
\qquad\left(\mathrm{Km}^{2}\right)\end{array}$} & \multicolumn{2}{|c|}{$\begin{array}{l}\text { Change in Barren Lands } \\
\left(\mathrm{Km}^{2}\right)\end{array}$} \\
\hline & 1986-1996 & 1986-2006 & 1986-1996 & 1986-2006 & 1986-1996 & 1986-2006 & 1986-1996 & 1986-2006 \\
\hline Marshyhope Creek & 13.1 & 4.4 & 16.7 & -11.9 & -27.9 & -8.2 & -8.4 & 2.2 \\
\hline Big Annemessex River & -4.1 & -6.6 & 1.2 & -7.5 & 3.2 & 8.7 & -0.1 & -0.1 \\
\hline Nanticoke River & 1 & -7.7 & -23.5 & -28.8 & 17.6 & 17.8 & -7.4 & -2.4 \\
\hline Transquaking River & 4.2 & -13.1 & 3 & -15.2 & -5 & 7.6 & -5.3 & -3 \\
\hline Fishing Bay & 57.7 & -53.2 & -7.2 & -21.3 & 40.6 & 11.7 & -2 & -1.9 \\
\hline Wicomico River Head & 4.3 & 2.8 & -7.8 & -10.3 & 2.2 & 1.2 & -2.6 & -1.7 \\
\hline Upper Pocomoke River & 56.9 & 13.6 & -65.5 & -28 & 5.1 & 5.8 & -3.4 & -3.2 \\
\hline Lower Wicomico R. & 5.8 & -0.7 & -16.2 & -33.7 & 11.7 & 21.1 & -9.9 & -8 \\
\hline Honga River & -10.4 & -13.7 & -2.3 & -4.5 & -0.8 & 8.1 & -0.4 & -0.4 \\
\hline Nassawango Creek & 13.7 & 5 & -10.2 & -9.6 & -1.6 & 3.8 & -3.1 & -2.7 \\
\hline Dividing Creek & -0.4 & -1.7 & 0.2 & -2.6 & -0.4 & 1 & -0.7 & -0.6 \\
\hline Wicomico Creek & 0.61 & -2.4 & -4.5 & -5.9 & 3.2 & 5.3 & -1.1 & -1.2 \\
\hline Monie Bay & -2.4 & -5.4 & -0.7 & -4.2 & 3.9 & 5.7 & -0.2 & -0.2 \\
\hline Manokin River & -7.5 & -13.5 & -10.2 & -13.8 & 14.6 & 17.9 & -2.2 & -2.1 \\
\hline Lower Pocomoke R. & -4.2 & -16.4 & -8 & -11.4 & 14.2 & 20.3 & -6.2 & -6.4 \\
\hline Tangier Sound & -5.5 & -17.4 & 2.1 & -1 & 0.8 & 8 & 0 & -0.1 \\
\hline Pocomoke Sound & -4.6 & -2.8 & -3.1 & -10.8 & 2.5 & 7 & -0.5 & -0.5 \\
\hline Assawoman Bay & 1.2 & -1.1 & -3.3 & -2.9 & 2.8 & 1.4 & -0.5 & 0 \\
\hline Isle Of Wight Bay & 14.9 & 1.9 & -25.5 & -16 & 10.4 & 6.1 & -2.1 & -1.3 \\
\hline Atlantic Ocean & 0.1 & 0 & 0 & -0.2 & 0.1 & 0 & -0.9 & -1 \\
\hline Newport Bay & 10.1 & 0.2 & -15.1 & -9.2 & 3.2 & 4.2 & -1.9 & -2.2 \\
\hline Sinepuxent Bay & 0.1 & -2.4 & -3 & -3.8 & 0.4 & 1.1 & 0.4 & 1.1 \\
\hline Chincoteague Bay & -5.7 & -19.9 & -3.8 & -3.7 & 12.8 & 15.8 & -6.5 & -6 \\
\hline
\end{tabular}

Most of the gains in urban land (56\% or $127.2 \mathrm{~km}^{2}$ ) occurred on agricultural lands with the greatest change occurring in the Lower Wicomico River sub-watershed $\left(18.3 \mathrm{~km}^{2}\right)$, Nanticoke River (13.1 km²), Upper Pocomoke River $\left(11 \mathrm{~km}^{2}\right)$, Marshyhope Creek $\left(10.2 \mathrm{~km}^{2}\right)$ and Lower Pocomoke River $\left(10.5 \mathrm{~km}^{2}\right)$ sub-watersheds. This trend is not unexpected considering the fact that residential developments and commercial growth attendant to increasing world population growth are not only occurring in urban centers but also in previously small towns and lands previously used for agricultural purposes [16]. About $33 \%\left(75.2 \mathrm{~km}^{2}\right)$ of urban land growth occurred on forested lands and the most significant loss to urbanization also occurred in the Lower Wicomico $\left(8.1 \mathrm{~km}^{2}\right)$, Marshyhope Creek $\left(8.1 \mathrm{~km}^{2}\right)$, Nanticoke River $\left(8.0 \mathrm{~km}^{2}\right)$ and Lower Pocomoke River $\left(7.1 \mathrm{~km}^{2}\right)$ sub-watersheds. This trend is similar to that reported in 2004 [7] where a $61 \%$ increase in developed lands within the Chesapeake Bay watershed from 1990-2000 were observed and were attributed mostly to new urban development (64\%) occurring on agricultural lands and grasslands, while 33\% occurred on forested lands. The National Oceanic and Atmospheric Administration [17] data also showed a similar trend for the Lower Eastern Shore between 1996 and 2005. A total loss of approximately $12.7 \mathrm{~km}^{2}$ of wetlands to urbanization occurred, while $8.2 \mathrm{~km}^{2}$ of barren land were converted to urban lands during the 20-year study period.

The total populations of the Lower Eastern Shore counties (Dorchester, Somerset, and Wicomico and Worcester counties) were approximately 155,708 in 1986, 176,905 in 1996 and 198,155 in 2006. At an average annual growth rate of $0.98 \%$, the projected population for 2030 was 249,700 and will double the population in 2070 [18]. Therefore, the gains in urban land can be attributed to the changes in the demography of the major cities/towns in the sub watersheds. For example, Salisbury, in the Lower Wicomico River sub watershed has been experiencing a rapid growth in housing development due to increase in population from approximately 16,850 in 1986 to 27,172 in 2006; a 61\% increase [18]. Urbanization in Marshy hope Creek (12.22 $\left.\mathrm{km}^{2}\right)$ can be attributed to population growth in Federalsburg and Hurlock while population growth in towns such as Hebron, Vienna, Mardela Springs and Sharp town is responsible for the $15.4 \mathrm{~km}^{2}$ increase in urban land use observed in Nanti- 
coke River sub-watershed. Population growth in Pocomoke City and Snow Hill are mainly responsible for the $11.7 \mathrm{~km}^{2}$ increase in urban land use in Lower Pocomoke River sub watershed. A combined urban land gain of $7.2 \mathrm{~km}^{2}$ in Isle of Wight and Assawoman Bay is due to population growth in Ocean City-a popular tourist city in the Eastern Shore of Maryland.

\subsection{Agricultural Land Use}

There was a net loss of about $256.16 \mathrm{~km}^{2}$ (19.6\%) of cropland in the Lower Eastern Shore sub-watersheds between 1986 and 2006 in general. The largest net loss of cropland occurred in the Lower Wicomico River sub-watershed (Table 2). In this sub-watershed, croplands decreased from 108.6 to $74.9 \mathrm{~km}^{2}$ from $1986-2006$. However, there were no significant differences in cropland use between 1986 and 1996, 1996 and 2006 or 1986 and $2006(\mathrm{P}<0.70, \mathrm{H}=0.83, \mathrm{n}=23)$. This finding was corroborated with the Census of Agriculture conducted by the United States Department of Agriculture (USDA) every five years that showed a decline in the use of land for crop production [19]. Croplands in Maryland decreased consistently over the years from 686,964 ha in 1987 to 553,324 ha in 2007 , representing a $19.5 \%$ loss.

The greatest loss of croplands occurred in the Lower Wicomico River sub-watershed followed by Nanticoke River and Upper Pocomoke River sub-watersheds. A total of $127.2 \mathrm{~km}^{2}$ of land was lost to urban sprawl. A large land mass $\left(457.3 \mathrm{~km}^{2}\right)$ of agricultural land was also converted into forest lands during the study period; they include Nanticoke River (58.4 km²), Upper Pocomoke River (49.9 km²), Marshyhope Creek (42.5 km²), Lower Wicomico River (39.2 km²), Lower Pocomoke River (41.1 km²) and Transquaking River $\left(36.2 \mathrm{~km}^{2}\right)$.

Forest lands were also lost to agriculture $\left(301.61 \mathrm{~km}^{2}\right)$ between 1986 and 2006 in the Lower Eastern Shore with most of those changes occurring in Marshyhope Creek $\left(40.5 \mathrm{~km}^{2}\right)$, Nanticoke River $\left(40.8 \mathrm{~km}^{2}\right)$, Upper Pocomoke River $\left(33.3 \mathrm{~km}^{2}\right)$, Lower Pocomoke River $\left(18.3 \mathrm{~km}^{2}\right)$ and Transquaking River $\left(27.6 \mathrm{~km}^{2}\right)$ sub-watersheds. Cropland conversion to wetland change was $54.83 \mathrm{~km}^{2}$ while approximately $21.6 \mathrm{~km}^{2}$ of cropland in 1986 became barren in 2006. Marshyhope Creek and Nanticoke River sub-watersheds lost $7.5 \mathrm{~km}^{2}$ and $4.6 \mathrm{~km}^{2}$ of cropland respectively to barren lands during the period. About $636.9 \mathrm{~km}^{2}$ (about $47 \%$ of croplands) remained unaltered during the same period especially in the Upper Pocomoke River $\left(109.3 \mathrm{~km}^{2}\right)$ and the Nanticoke River sub watersheds $\left(75.2 \mathrm{~km}^{2}\right)$. While a total of $250.2 \mathrm{~km}^{2}$ cropland was lost to other uses during the study period, an average of $11.14 \pm 1.5 \mathrm{~km}^{2}$ were lost per sub-watershed.

\subsection{Forest Land Use}

Very substantial areas of forest lands $\left(1,447.3 \mathrm{~km}^{2}\right.$ or $\left.71 \%\right)$ remained unaltered between 1986 and 2006 for Lower Pocomoke River, Upper Pocomoke River, Nanticoke River, Fishing Bay and Marshyhope Creek. However, whereas forest land occupied 2022.6km² in 1986, only 2,193.9 $\mathrm{km}^{2}$ remained in 2006 (Table 1), with a net gain of $171.3 \mathrm{~km}^{2}$ (8.5\%) during the 20-year period. The recent U.S Census of Agriculture (USDA, 2009) reported increase in woodlands and pastures in Maryland in general. However, this change was not significant between time interval investigated ( $\mathrm{P}<0.90, \mathrm{H}=0.28, \mathrm{n}=23$ ). Although forest lands increased in most sub-watersheds, Marshyhope Creek sub-watershed actually experienced a net loss of $8.2 \mathrm{~km}^{2}$ (Table 2). This result is corroborated by the NOAA land use-land cover data which also showed an increase in forested lands for the Lower Eastern Shore between 1996 and 2005 [17]. Increase in forest land in the Lower Eastern Shore can be attributed to natural forest re-growth and Maryland Forest Conservation Act enacted in 1991. This Act stipulates that, "gaining approval of the required Forest Conservation Plan (development of more than one acre) may require long term protection of included priority areas or planting/replanting (Afforestation or reforestation) a sensitive area off-site” [20]. The largest net gain in forest land $\left(21.1 \mathrm{~km}^{2}\right)$ during the study period was in the Lower Wicomico sub-watershed. Gains in forest land from other land uses decreased in the following order: cropland to forest $\left(457.3 \mathrm{~km}^{2}\right)$, wetland to forest $\left(204.5 \mathrm{~km}^{2}\right)$, urban to forest $\left(38.5 \mathrm{~km}^{2}\right)$, water to forest $(27.5$ $\mathrm{km}^{2}$ ) and barren land to forest $\left(19.9 \mathrm{~km}^{2}\right)$.

\subsection{Surface Water Cover}

There was a net gain of about $135.9 \mathrm{~km}^{2}(10 \%)$ of areas covered by water in the Lower Eastern Shore sub-watersheds between 1986 and 2006. During this period, however, $154.6 \mathrm{~km}^{2}$ of wetlands became inundated. Most of this inundation occurred in Fishing Bay $\left(55.8 \mathrm{~km}^{2}\right.$ ) (Figure 3) situated at the edge of Chesapeake Bay in 


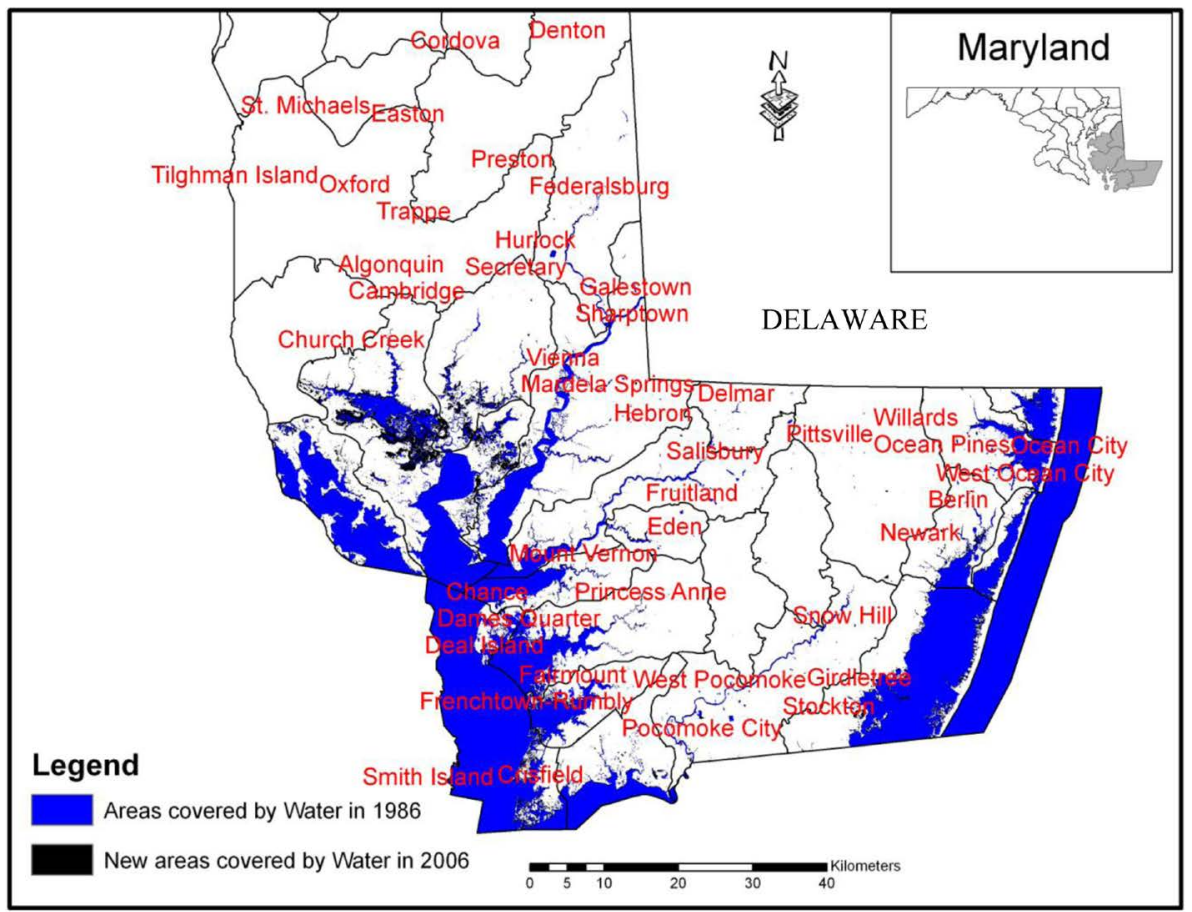

Figure 3. New areas covered by water between 1986 and 2006 in the Lower Eastern Shore of Maryland.

Dorchester county. Conversely, only $31.4 \mathrm{~km}^{2}$ of water covered areas in 1986 became wetlands in 2006 with Fishing Bay also experiencing the most change of $6.4 \mathrm{~km}^{2}$. Some forested lands $\left(32.2 \mathrm{~km}^{2}\right)$ were also inundated by water during the study period, while $9.6 \mathrm{~km}^{2}$ of agricultural lands also became inundated with water. About $6.6 \mathrm{~km}^{2}$ of urban lands similarly became inundated by water while a total change from barren land to water in the Lower Eastern Shore was $1.63 \mathrm{~km}^{2}$ during the study period. Increase in water cover in the Lower Eastern Shore of Maryland is due in part to sea-level rise-perhaps a global warming effect on the estuarine tributaries of the Chesapeake Bay which empties into the Atlantic Ocean. This rise is indicated by the decrease in the extent of wetlands and salt marshes (by 22\%) through submergence, and barren land (which decreased by 2\%) during the study period. This observation is supported by the work of scientists in the Chesapeake Bay area at the Virginia Institute of Marine science [21]-[23]. In addition, Hilbert [24] reported a similar trend in the Grand Bay National Estuarine Research Reserve area of Mississippi in the Northern coast of Gulf of Mexico from 1974 to 2001.

\subsection{Wetland Cover}

Loss of wetlands was observed in 17 out of the 23 sub-watersheds in the study area (Table 2). There was a 23\% net loss $\left(150.0 \mathrm{~km}^{2}\right)$ of wetlands from 1986-2006 in the study area. Similar results were observed in NOAA land use-land cover data which also showed loss of wetlands for the Lower Eastern Shore between 1996 and 2005 [17]. The Congaree Bottomland Hardwood Swamp in South Carolina was estimated to remove pollutants equivalent to that removed annually by a $\$ 5$ Million waste water treatment plant [25]. The decreasing extent of wetlands in the Lower Eastern Shore has the potential to compromise several ecological services performed by this habitat.

Our results also indicate that during the study period, $154.6 \mathrm{~km}^{2}$ of wetlands became inundated with water (see Figure 4). Most of the inundation (55.8 $\mathrm{km}^{2}$ representing 41\%) occurred in Fishing Bay where the largest net loss of $53.2 \mathrm{~km}^{2}$ (35\%) of wetlands occurred. Nutria (Myocastor coypus) has been a primary force in accelerating wetland loss in the Black water basin-where Fishing Bay is located; as well as other sub-watersheds in Maryland. Nutria feed on marsh vegetation, expose the mud and thereby predispose marshes to erosion. Consequently, the marsh surface sinks and the vegetation is lost to flooding. Large area of marsh lands in the Black 


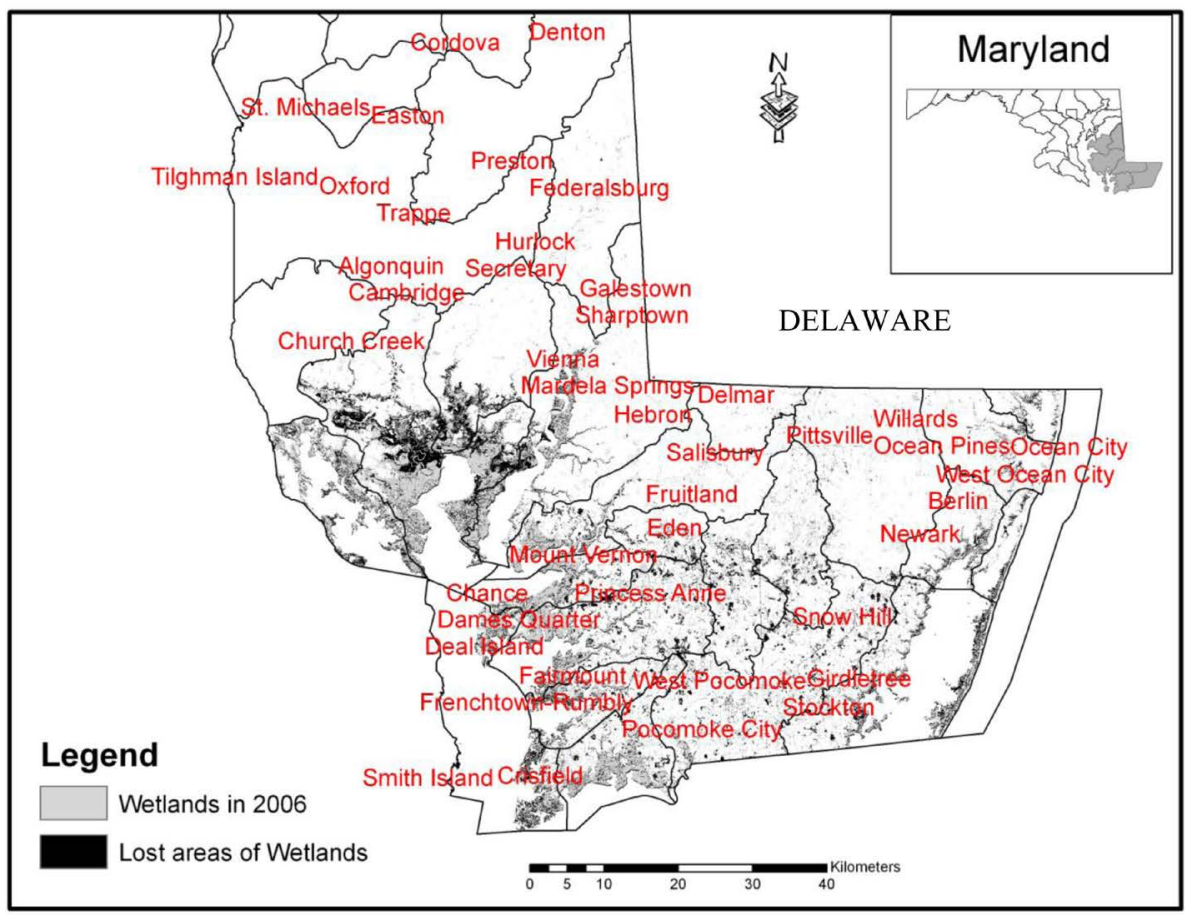

Figure 4. Lost areas of wetland between 1986 and 2006 in the Lower Eastern Shore of Maryland.

water National Wildlife Refuge (BNWR) within the same watershed has been lost to nutria [26]. Although, this destructive rodent has been eradicated from BNWR [11], 53\% of the remaining marshes in BNWR is considered unhealthy and is likely to be lost in the future [26]. It is obvious therefore that the activities of these non-native rodent species on the wetlands may have contributed in part to the decreasing wetlands and increasing extent of water cover in the Lower Eastern Shore of Maryland.

Reciprocally, only $31.44 \mathrm{~km}^{2}$ of areas covered by water in 1986 have become wetlands in 2006 with Fishing Bay also experiencing the most change of $6.4 \mathrm{~km}^{2}$. This indicates, fluctuations between areas covered by water and wetland in Fishing Bay but with more wetlands becoming flooded. Of the $704.3 \mathrm{~km}^{2}$ of wetlands in 1986 , only $299.56 \mathrm{~km}^{2}$ (or 43\%) have remained unaltered between 1986 and 2006, especially in Fishing Bay (79.3 $\mathrm{km}^{2}$ ), Nanticoke River (35.4 km²), Honga River (29.6 km²) and Manokin River (25.9 km²) sub-watersheds. Approximately $204.5 \mathrm{~km}^{2}$ of wetlands became forested between 1986 and 2006. Most of this change has occurred in the Lower Pocomoke River (25 km²), Manokin River (23.7 km²) sub-watersheds as well as Fishing Bay (21.6 $\mathrm{km}^{2}$ ). A total of $34.9 \mathrm{~km}^{2}$ of wetlands was lost to cropland use in the study region between 1986 and 2006 . Small areas of wetlands also changed to cropland in the Lower Pocomoke River (5.4 km²), Manokin River (3.4 km²) and Fishing Bay $\left(3.0 \mathrm{~km}^{2}\right)$. About $12.7 \mathrm{~km}^{2}$ of wetlands became urbanized in 2006. Lost areas of wetland between 1986 and 2006 are shown in Figure 4.

\subsection{Barren Lands}

There was a decrease in barren lands (51.3\%) in all the sub watersheds except for Marshyhope Creek (with a net gain of $2.2 \mathrm{~km}^{2}$ ), and Sinepuxent Bay $\left(1.1 \mathrm{~km}^{2}\right.$ ); however, Assawoman Bay experienced no net gain (See Table 2). Barren lands, which are mainly beaches in Assawoman Bay and Isle of Wight Bay near Ocean City (a popular tourist city) experienced increase in water-covered areas by $2.1 \mathrm{~km}^{2}$ and $2.7 \mathrm{~km}^{2}$ in Assawoman Bay and Isle of Wight Bay respectively. This may be due to the rising sea level—a trend which has also been reported by Hilbert [24] in the Grand Bay National Estuarine Research Reserve area of Mississippi in the Northern coast of Gulf of Mexico from 1974-2001. The Lower Eastern Shore sub-watersheds recorded a significant net loss of about $41.6 \mathrm{~km}^{2}$ of barren lands between 1986 and $2006(\mathrm{P}<0.05, \mathrm{H}=13.28, \mathrm{n}=23)$. Barren land significantly $(\mathrm{P}<0.05)$ decreased from $80.2 \mathrm{~km}^{2}$ in 1986 to $17.2 \mathrm{~km}^{2}$ in 1996 ; however, changes between 1996 and 
2006 were not significant.

About $43.2 \mathrm{~km}^{2}$ of barren land was converted to cropland, while $8.19 \mathrm{~km}^{2}$ was converted to urban land. As of 2006, approximately $19.4 \mathrm{~km}^{2}$ of barren lands became forested within the 20-year period, with the largest changes occurring in the Lower Wicomico River $\left(2.7 \mathrm{~km}^{2}\right)$, Marshyhope Creek $\left(2.4 \mathrm{~km}^{2}\right)$ and Nanticoke River $\left(2.0 \mathrm{~km}^{2}\right)$ sub-watersheds. Only $6.7 \mathrm{~km}^{2}$ of barren land remained unaltered especially in the Marshyhope Creek $\left(1.6 \mathrm{~km}^{2}\right)$.

\section{Discussion}

Ecosystem services in practical terms are essentially the conditions, processes, and components of the natural environment that provide both tangible and intangible benefits for sustaining and fulfilling human life [27]. The Millennium Ecosystem Assessment [3] framework identifies four categories of ecosystem services that include: supporting services, provisioning services, regulating services, and cultural services. Based on these services we evaluated the possible impact of the changes in land use/cover during the 20-year study period on ecosystem services/health for the respective land use/cover classes as follows:

\subsection{Impact of the Increasing Urban Land Use on Ecosystem Health}

The increase in urban land during the two decade is due to the increasing population of the Eastern Shore counties that experienced a total of $227.3 \mathrm{~km}^{2}$ of land converted from other uses due to the need for new real estate and other public infrastructure. Such growth in urban lands create impervious surfaces and thus reduces infiltration, and increase the loading of nutrients, sediment and other contaminants into the aquatic ecosystems as has been previously reported (e.g., Tang et al., [28], Mallin et al., [29] and Van Buren et al., [30]). For this study site and period, the increasing trends in urban land use is reducing the ecosystem services such as carbon sequestration from the parcel of land previously used for agriculture and/or forestry and thus aggravating the global warming trends now at the center of global discuss the world over. Similarly, the capacity to provide services such as clean water is being compromised by the unavoidable pollutions from nonpoint sources from runoff, atmospheric deposition, as well as point-sources from increasing sewage loadings from the growing wastewater treatment plants in the area. The dissolved oxygen levels in the surface waters for this site and period have been reported to show a declining trend while nutrient loading (Phosphorus and Nitrate) have increased with serious implications for eutrophication [31]. Eutrophication of surface water systems compromises their capacity to support cheap water supply, destroys habitat for aquatic organisms that supplies human food as well as clean water for recreation.

\subsection{Impact of the Declining Agricultural Land Use on Ecosystem Health}

Despite its crucial role in feeding the world population, agriculture remains the largest driver of genetic erosion, species loss and conversion of natural habitats [3]. Thus the loss of $256.2 \mathrm{~km}^{2}$ of Agricultural land from 1986-2006 in the Lower Eastern Shore watersheds to other land uses has mixed consequences from an ecological health standpoint. Whereas such changes indicate a decreased capacity of the terrestrial ecosystem's ability to support ecological service of photosynthesis and thus carbon sequestration during the growing seasons, this impact has to be weighed against the land uses that replaced the original agricultural lands. For instance, biodiversity may have improved if the croplands-which are predominantly monocrops gave way to forest lands. However, if replaced by urban development, the impact on ecosystem health could have been negative during the period as it could have reduced the capacity to support carbon sequestration, thereby increasing global warming. On the other hand, the loss of Agricultural lands is also compromising ability of the land to support food and thus food security. Because increasing food energy efficiency provides a critical path for significant growth in food supply without compromising environmental sustainability [3], the dwindling agricultural land in the past two decades for this study site calls for the need to support the adoption of more energy-efficient technologies by commercial farmers.

\subsection{Impact of the Increasing Forest Land Use on Ecosystem Health}

Forests provides a broad range of ecological services that includes: the regulation of water regimes by intercepting rainfall and regulating its flow through the hydrological system; the maintenance of soil quality and the pro- 
vision of organic materials through leaf and branch fall; limiting of erosion and protection of soil from the direct impact of rainfall; modulating climate; and being key components of biodiversity both in themselves and as a habitat for other species. The result of this study indicated a positive change during the study period albeit modest. The forest land area increased by an average of $7.6 \pm 1.5 \mathrm{~km}^{2}$ per year during the study period and thus is noteworthy for the sub-watersheds because losses occurring in some areas were made up by some gains elsewhere-perhaps due to tree planting in the growing urban neighborhoods or natural forest regrowth. In view of the numerous ecological services provided by forests as listed above, this change is rather positive and thus should be encouraged using well tested policy initiatives in the future.

\subsection{Impact of the Increasing Surface Water Cover on the Ecosystem Health}

The increase in the extent of surface water cover-attributable to the global warming and resultant rise in sea level is significant; however, the increase was mostly at the expense of the shrinking wetlands during the 20-year period. Fromhoff et al., [21] reported that global warming is already having an impact on the Chesapeake Bay. The anticipated impact of sea level rise on the local coastal habitat of the Chesapeake Bay have been documented [32]; this work was based on extensive coastal data and literature available on wetlands, shoreline types and condition, as well as location, erosion, future protection, and habitat types.. This study has confirmed-albeit indirectly, the impact of global warming and sea level rise-as a total of $135 \mathrm{~km}^{2}$ increases in the extent of water coverage in two decades occurred as well as the inundation of wetlands in the area investigated. The expanding water surface constitutes land take, thus reducing the extent of the finite land area and thus shrinks the available terrestrial ecosystem which provides services such as carbon sequestration and storage as soil organic matter and the support of wildlife. Furthermore, changes in the salinity could have affected some species as the extent of mixing of freshwater and saline water from the Atlantic Ocean could have occurred.

Of even greater impact is the loss of wetlands (about $150 \mathrm{~km}^{2}$ ) during the period in 17 out of the 23 sub-watersheds from 1986-2006 — an average loss of $6.52 \pm 2.3 \mathrm{~km}^{2}$ every year. Except if checked, this will continue to threaten the ecological balance of the area as wetlands are increasingly being credited for performing several ecosystem services such as regulating water purity, storm surge, hurricane protection, groundwater recharge, provision of habit for shellfishes and waterfowls [33]. The shrinking wetland is also being accelerated by the presence of Nutria - an invasive species common in the area and is currently being addressed [34]. Some of the anticipated impact documented for the Eastern shore coastal areas which may already be taking place in this and possibly the adjoining coastal areas [32] include: loss of tidal flats, crabs, juvenile fish and the larger fish and waterfowl that feed on them. Because bird communities in large marshes cannot persist in habitat patches of less than 5 ha (12.4 acres) [35], the loss of wetlands to inundation with water could lead to a decline in bird population in some areas; and could have dramatic effect on local estuarine food webs. Loss of these birds could also remove a significant amount of biomass from the shore habitats.

\subsection{Impact of the Decreasing Barren Land on the Ecosystem Health}

There was a net loss of barren land-most of which is the beaches along the Atlantic coast including the barrier island such as Ocean City, MD. The loss was due to the increasing surface water cover whose impact includes a reduction in the extent of beach land used for recreational activities. A continuation of this trend could have a significant impact on tourism in the future in addition to the ecological and cultural services provided by the beaches in the area. Long term, it also threatens the existence of the various barrier islands in the area. Beside the beaches, the decrease in other barren lands such as those on fallow may be attributable to their conversion to other uses; this may be positive (e.g., when converted to forestry) or negative (when converted to real estate/urban development) from an ecosystem service standpoint.

\section{Summary and Conclusions}

Urban land area increased as well as forest lands in the Lower Eastern Shore watersheds from 1986-2006. However, there were net losses of agricultural lands, wetlands and barren lands during the same period. Most of the urban land gain occurred on croplands, while about a third occurred on forested land. Net area covered by water increased by $135.9 \mathrm{~km}^{2}$ for all sub-watersheds and $154.61 \mathrm{~km}^{2}$ of wetlands was inundated or covered by water; and was attributed to the rising sea level as these tributaries of the Chesapeake Bay empties into the At- 
lantic Ocean. The loss of wetlands around Fishing Bay where Blackwater National Wildlife Refuge is located needs urgent solutions. Also the presence of the destructive feeding activities of Myocastor coypu (Nutria), a non-native rodent species feeding on marsh vegetation there requires an urgent solution. Summarily, it can be concluded that the changes in the land use/cover of these Lower Eastern Shore sub-watersheds from 1992-2006 is already impacting the ecological health in very significant ways; a) the declining Agricultural land indicates the decline of ecological services such as the provision of food, fiber, nutrient cycling and cultural heritage; to this end, farming practices that can be better managed to minimize the impact of ecosystems is needed $b$ ) the declining wetlands is impacting the coastal ecosystem's ability to provide services such as food, fiber, nutrient cycling, storm and wave protection, recreation and ecotourism and aesthetic values; c) the expanding surface water cover threatens the barrier islands-Ocean city, Assateague Island, Chincoteague national Wildlife Refuge in Chincoteague Island and other coastal communities in the future; furthermore, it could potentially impact recreation and ecotourism in the area; d) the expanding forest land use is a positive development that should be promoted through policy initiatives because of the provisioning of food, timber, freshwater, fuel wood, flood relation, disease regulation, carbon sequestration, local climate regulations, aesthetic and spiritual values. The increasing urban land resulting from population-driven infrastructural development could result in increasing point and non-point source pollution of surface waters; this could compromise surface water systems' ability to supply clean water for human consumption and other cultural uses. Policy initiatives to regulate land use from an ecological health standpoint for ensuring the sustainability of the various types of ecosystems are urgently needed for Maryland Eastern Shore watersheds and similar locations in the US and elsewhere.

\section{References}

[1] Costanza, R., Norton, B.G. and Haskell, B.D. (1992) Ecosystem Health: New Goals for Environmental Management. Island Press, Washington DC.

[2] CERF (2011) Valuing Ecosystems Services, Assessing Choices. http://cerf2011.blogspot.com/2011/10/valuing-ecosystem-services-assessing.html

[3] MA (2003) Ecosystems \& Human Well-Being: Wetlands \& Water. World Resources Institute, Washington DC.

[4] Dale, V.H., Brown, S., Haeuber, R., Hobbs, N.T., Huntly, N., Naiman, R.J., Riebsame, W.E., Turner, M.G. and Valone, T. (2000) Ecological Principles and Guidelines for Managing Use of Land. Ecological Applications, 10, 639-670.

[5] Gergel, S.E., Turner, M.G., Miller, J.R., Melack, J.M. and Stanley, E.H. (2002) Landscape Indicators of Human Impacts to Riverine Systems. Aquatic Science, 64, 118-128. http://dx.doi.org/10.1007/s00027-002-8060-2

[6] Palmer, M.A., Moglen, G.E., Bockstael, N.E., Brooks, S., Pizzuto, J.E., Wiegand, C. and VanNess, K. (2002) The Ecological Consequences of Changing Land Use for Running Waters: The Suburban Maryland Case. Yale Bulletin of Environmental Science, 107, 85-113.

[7] Jantz, P., Goetz, S. and Jantz, C.A. (2004) Urbanization and the Loss of Resource Lands within the Chesapeake Bay Watershed. Environmental Management, 36, 808-825. http://dx.doi.org/10.1007/s00267-004-0315-3

[8] Menzie, C.A., Deardoff, T., Booth, T. and Wickwire, T. (2012) Refocusing on Nature: Holistic Assessment of Ecosystem services. Integrated Environmental Assessment and Management, 8, 401-411.

[9] Rapporta, D.J., Constanza, R. and McMichaeld, A.J. (1998) Assessing Ecosystem Health. Trends in Ecology \& Evolution, 13, 397-402. http://dx.doi.org/10.1016/S0169-5347(98)01449-9

[10] Merem E., Robinson, B., Wesley, J.M., Yerramilli, S. and Twumasi, Y.A. (2010) Using GIS in Ecological Management: Green Assessment of the Impacts of Petroleum Activities in the State of Texas. International Journal of Environmental Research and Public Health, 7, 2101-2130. http://dx.doi.org/10.3390/ijerph7052101

[11] Washington Post (2004) Blackwater Refuge Now Nutria-Free: Marsh-Demolishing Rodent Fended off Earlier. http://www.washingtonpost.com/wp-dyn/articles/A55356-2004 Nov16.html

[12] US Environmental Protection Agency (2009) Surf Your Watershed. http://cfpub.epa.gov/surf/locate/hucperstate_search.cfm?statepostal=MD

[13] Anderson, J.R., Hardy, E.E., Roach, J.T. and Witmer, R.T. (1976) A Land Use and Land Cover Classification System for Use with the Remote Sensor Data. Geological Survey Professional Paper 964. A Revision of the Land Use Classification System as Presented in US Geological Survey Circular, 671.

[14] Environmental Systems Research Institute (ESRI) (2007) ArcGIS9.2. Redlands, CA. USA.

[15] Aighewi, I.T. and Nosakhare, O.K. (2013) Geospatial Evaluation for Ecological Watershed Management: A Case Study of Some Chesapeake Bay Sub-Watersheds in Maryland USA. Journal of Geographic Information System, 5, 
354-368.

[16] Carlson, T.N. and Arthur, S.T. (2000) The Impact of Land Use-Land Cover Changes Due to Urbanization on Surface Microclimate and Hydrology: A Satellite Perspective. Global and Planetary Change, 25, 49-65. http://dx.doi.org/10.1016/S0921-8181(00)00021-7

[17] National Oceanic and Atmospheric Administration (2007) Coastal Services Centre. Land Cover Analysis: Northeast Land Cover.

https://data.noaa.gov/dataset/noaa-coastal-change-analysis-program-ccap-2001-era-land-cover-data-of-thenorth-atlantic-united

[18] Maryland Department of Planning (2006) Historical and Projected Total Population for Maryland's Jurisdictions. Planning Data Services. http://www.mdp.state.md.us/msdc/

[19] United States Department of Agriculture (2009) http://www.agcensus.usda.gov./Publications/2007/Full_Report/Volume_1,_Chapter_1_State_Level/Maryland/st24_1_ 001_001.pdf

[20] Maryland Department of Natural Resources (1995) Forest Service: Urban and Community Forestry. Forest Conservation Act. http://www.dnr.state.md.us/forests/programapps/newFCA.asp.

[21] Frumhoff, P.C., McCarthy, J.J., Melillo, J.M., Moser, S.C. and Wuebbles, D.J. (2007) Confronting Climate Change in the U.S. Northeast: Science, Impacts, and Solutions. Synthesis Report of the Northeast Climate Impacts Assessment (NECIA). Union of Concerned Scientists (UCS), Cambridge.

[22] Boon, J.D. (2012) Evidence of Sea Level Acceleration at U.S. and Canadian Tide Stations, Atlantic Coast, North America. Journal of Coastal Research, 28, 1437-1445. http://dx.doi.org/10.2112/JCOASTRES-D-12-00102.1

[23] Boon, J.D., Brubaker, J.M. and Forrest, D.R. (2010) Chesapeake Bay Land Subsidence and Sea Level Change: An Evaluation of Past and Present Trends and Future Outlook. US Army Corps of Engineers Report.

[24] Hilbert, W.K. (2006) Land Cover Change within the Grand Bay National Estuarine Research Reserve: $1974-2001$. Journal of Coastal Research, 22, 1552-1557. http://dx.doi.org/10.2112/05-0582.1

[25] U.S Environmental Protection Agency (2008) Watersheds Academy: Wetland functions and values. http://www.epa.gov/watertrain/wetlands/index.htm

[26] US Fish and Wildlife Service (2009) Blackwater National Wildlife Refuge: Nutria and Blackwater Refuge. http://www.fws.gov/blackwater/nutriafact.html\#damage.

[27] Daily, G.C. (1997) Nature’s Services. Societal Dependence on Natural Ecosystems. Island Press, Washington DC, 392 p.

[28] Tang, Z., Engel, B.A., Pijanowski, B.C. and Lim, K.J. (2005) Forecasting Land Use Change and Its Environmental Impact at a Watershed Scale. Journal of Environmental Management, 76, 35-45. http://dx.doi.org/10.1016/j.jenvman.2005.01.006

[29] Mallin, M.A., Johnson, V.L., Ensign, S.H. and MacPherson, T.A. (2006) Factors Contributing to Hypoxia in Rivers, Lakes, and Streams. Limnology and Oceanography, 51, 690-701. http://dx.doi.org/10.4319/lo.2006.51.1_part_2.0690

[30] Van Buren, M.A., Watt, W.E., Marsalek, J. and Anderson, B. (2000) Thermal Enhancement of Storm Water Runoff by Paved Surfaces. Water Research, 34, 1359-1371. http://dx.doi.org/10.1016/S0043-1354(99)00244-4

[31] Aighewi, I.T. and Nosakhare, O.K. (2012) Land Use-land Cover Changes and Sewage loading in the Lower Eastern Shore Watersheds and Coastal Bays of Maryland: Implications for Water Quality. Journal of Coastal Research, 29, 1073-1082.

[32] Titus, J.G., Jones, R. and Streeter, R. (2008) Maps that Depict Site-Specific Scenarios for Wetland Accretion as Sea Level Rises along the Mid-Atlantic Coast. Section 2.2. In: Titus, J.G. and Strange, E.M., Eds., Background Documents Supporting Climate Change Science Program Synthesis and Assessment Product 4.1, EPA 430R07004, US EPA, Washington DC.

[33] Mayer, J.R. (2001) Connections in Environmental Science. McGraw Hill, Boston, 87-102.

[34] Chesapeake Bay Foundation (2012) Annual Report of the Chesapeake Bay Foundation. Chesapeake Bay Foundation, Washington DC, 1-6.

[35] Strange, E.M., Shellenbarger Jones, A., Bosch, C., Jones, R., Kreeger, D. and Titus, J.G. (2008) Mid-Atlantic Coastal Habitats and Environmental Implications of Sea Level Rise. Section 3. In: Titus, J.G. and Strange, E.M., Eds., Background Documents Supporting Climate Change Science Program Synthesis and Assessment Product 4.1, EPA 430R07004, US EPA, Washington DC, 299. 